\title{
PORNOGRAFÍA Y FEMINISMO RADICAL ${ }^{*}$
}

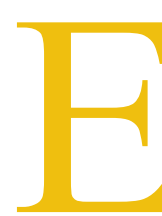

1 feminismo radical es, sin duda, un declarado enemigo de la pornografía. Las feministas radicales han sido, junto al sector conservador más reaccionario de la sociedad, quienes con mayor virulencia han abogado, tanto en el terreno teórico como en el de las acciones políticas, por la necesidad de una censura absoluta de la pornografía. La publicación de trabajos de diversa índole -académica, ideológica o directamente política-, manifestaciones públicas de protesta, acciones civiles y penales contra productores y distribuidores de material pornográfico, apedreamiento de escaparates de locales dedicados a la venta de pornografía, etc., han sido algunas de las formas de oposición a la pornografía utilizadas por ese colectivo. Este proceso de duro enfrentamiento tuvo su culminación en la ordenanza que, según un modelo propuesto por las feministas estadounidenses Andrea Dworkin y Catharine MacKinnon, aprobó un dividido Consejo del Ayuntamiento de la ciudad de Minneápolis a finales de 1983. Y aunque esa resolución fuera posteriormente vetada por el Alcalde Donald Fraser, sólo unos pocos meses después el Ayuntamiento de Indianápolis, enarbolando la bandera de la lucha antipornográfica, promulgó una versión algo modificada de esa disposición.

Esta última norma fue declarada inconstitucional por las autoridades jurisdiccionales federales al constituir una violación a la Primera Enmienda de la Constitución estadounidense. Decisión ratificada por la Corte de Apelaciones en agosto de 1985 y posteriormente por la Suprema Corte en febrero de 1986. Pese a ello, elementos del partido republicano, miembros de la llamada mayoría moral silenciosa, grupos de ciudadanos en

* Este trabajo ha sido posible gracias a la ayuda prestada por la Dirección General de Investigación Científica y Técnica al equipo investigador de Filosofía del Derecho de la Universidad Pompeu Fabra. 
favor de la decencia, todos ellos en connivencia con las feministas radicales -auto- 
proclamadas de izquierdas- propusieron la edición de disposiciones similares en Cambridge -Massachusetts-, Madison -Wisconsin- y Suffolk Country -New York-, entre otras localidades, aunque sin éxito ${ }^{1}$.

A pesar de los problemas constitucionales que adolecía la medida legislativa propuesta por A. Dworkin y C. MacKinnon, tal iniciativa tuvo el efecto de reavivar el debate sobre el papel que juega en las relaciones sociales la discriminación sexual en general y la pornografía en particular, introduciendo en la discusión algunos conceptos que tuvieron cierto impacto en los ámbitos político y jurídico.

En realidad, el movimiento antipornográfico protagonizado por el feminismo radical había comenzado unos años antes, en 1970. Precisamente el mismo año que Richard Nixon rechazaba el Informe que después de cuatro años de trabajo había elaborado la Comisión sobre la Obscenidad y la Pornografía de los Estados Unidos recomendando la no prohibición de la pornografía para aquellos adultos que consistieran a ella. Desde ese momento, las feministas radicales se apropiaron del término «pornografía» para hacer referencia a la representación de materiales explícitamente sexuales dirigidos a la satisfacción del placer sexual de los hombres mediante la explotación y subordinación de la mujer ${ }^{2}$. Este movimiento consideraba a la pornografía como un elemento central de un sistema político que se caracterizaba por el ejercicio constante del poder del hombre sobre la mujer. Y sus movilizaciones, bajo el lema «Take Back the Night», tuvieron lugar por aquellas fechas en numerosas ciudades americanas. Ahora bien, los argumentos utilizados por las feministas radicales se formulan de una manera bastante similar en todos aquellos países donde existen como movimiento. Si se presta una atención especial a lo sucedido en los EE.UU. es porque allí el debate adquirió mayor notoriedad y desarrollo. La bibliografía que originó es abundante y en las discusiones han participado algunos políticos, politólogos y juristas de prestigio. En líneas generales, los argumentos presentados son extrapolables a otros lugares.

${ }^{1}$ Para un análisis de las circunstancias políticas en que se desarrolló este proceso, véase: Downs, D., The New Politics of Pornography. The University of Chicago Press, 1989. También, Paul Brest y Ann Vandenberg, «Politics, Feminism, and the Constitution: The Anti-Pornography Movement in Minneapolis», en Stanford Law Review, vol. 39, febrero de 1987, págs. 607 y ss.; y Brigman W. «Pornography as Group Libel: The Indianapolis Sex Ordinance», en Indiana Law Review, vol. 18, 1985, n. $^{\circ} 2$, págs. 479 y ss.

${ }^{2}$ Véase, por ejemplo, Longino H. «Pornography, Oppression and Freedom, A Closer Look», en Lederer L. (ed.) Take Black the Night. William Morrow and Co. New York 1980, pág, 42. 
En la década de los 80 el movimiento antipornográfico, fomentado en buena parte por la oleada conservadora que vivía los Estados Unidos, cobró una mayor relevancia pública, si cabe, acaparando la atención de los medios de comunicación. Fue en este contexto cuando, a finales de 1983, A. Dworkin y C. MacKinnon fueron invitadas por la Minnesota Law School a dictar un curso sobre la pornografía. Mientras tanto, en la ciudad de Minneápolis se había constituido la Neighborhood Pornography Task Force con el objeto de presionar al Ayuntamiento para que restringiera a una única zona la posibilidad de distribución y venta de material pornográfico. Las dos feministas americanas citadas fueron exhortadas a sumarse a esa iniciativa, y aunque declinaron en principio la oferta por considerar el establecimiento de aquella zona específica una maniobra política reformista y una respuesta inadecuada al daño que causa la pornografía marcó el comienzo de una estrecha colaboración entre ambas y las fuerzas conservadoras de esa localidad; colaboración que culminó en una propuesta legislativa en favor de la censura de la pornografía.

Analizar el entramado del modelo de ordenanza propuesto en Minneápolis e Indianápolis resulta interesante porque permite examinar la actitud del feminismo radical hacia la pornografía, como así también la concepción que sobre la mujer, la relación entre los sexos y la sociedad a esa actitud subyace; a la vez que pone de manifiesto con claridad las alianzas políticas concretas que estos colectivos radicales realizan. Prestar atención a las tesis de A. Dworkin y C. MacKinnon tiene un cierto interés si se piensa en la repercusión que sus obras alcanzaron en los medios académicos universitarios y en el movimiento feminista en general. Hablar del feminismo radical y no del feminismo a secas, por otra parte, constituye una limitación del objeto de análisis necesaria. El feminismo no es una doctrina, un movimiento político o una ideología unitaria y coherente. Y aquello que enuncia una auto considerada feminista suele ser inmediatamente contradicho por otra de sus pares. La falta de presupuestos comunes en cuestiones morales, ideológicas y metodológicas, como así también la diversidad de objetivos, tácticas o estrategias políticas y la carencia de una propiedad común que permita identificar indubitablemente a los miembros de este movimiento condujo a la feminista Laura Brown a decir que «el feminismo es cualquier cosa que digamos que es»» ${ }^{3}$. Que tal sea el caso explica y, en mi opinión, justifica que

${ }^{3}$ Citado por Alice Echols, «El ello domado: la política sexual feminista entre 1968-83", en Vance C. (comp.) Placer y peligro. Versión castellana: Julio Velasco y M. ${ }^{\mathrm{a}}$ Angeles Toda. Ed. Revolución. Madrid 1989, pág. 88. La propiedad de «feminista» sería, en ese caso, puramente 
centre la atención exclusivamente en el feminismo radical y, dentro de esa parcela, en algunas autoras determinadas ${ }^{4}$. En lo que sigue, me propongo: I. Presentar de una manera esquemática y breve el modelo de ordenanza antipornográfica propuesta por A. Dworkin y C. Mackinnon. II. Establecer cuáles son los presupuestos ideológicos, políticos y éticos que subyacen a esa ordenanza y III. Determinar cuál debería ser la actitud moralmente exigible, respecto de la pornografía, a un Estado constitucional.

La razón para la promulgación de la ordenanza en Minneápolis e Indianápolis era, en palabras de A. Dworkin y C. Mackinnon, que la pornografía viola los derechos civiles de las mujeres al constituir una práctica esencial en el proceso de discriminación y de subordinación sexual que convierte a la mujer en una ciudadana de segunda clase. De acuerdo a sus opiniones, habría una relación causal entre la pornografía y la opresión sistemática de la mujer. Según la exposición de motivos, el daño a las mujeres en la pornografía incluye su deshumanización y su explotación sexual, las relaciones sexuales y la prostitución forzadas, las agresiones, el terrorismo social y sexual, y la inferioridad de la mujer presentada como espectáculo. La pornografía -se agrega- crea acoso, persecución y denigración, tanto en público como en privado, y promueve agresiones y vejaciones tales como violaciones, malos tratos y el abuso sexual de niñas y niños.

Para mostrar este extremo, las promotoras, junto a la feminista conservadora miembro del partido republicano Charlee Hoyt, realizaron diversas audiencias públicas, uno de cuyos objetivos era entrevistar a supuestas víctimas de la pornografía. Esposas que habían sido obligadas por sus ex maridos a realizar prácticas sexuales calificadas como denigrantes aprendidas de libros y revistas pornográficas; prostitutas maltratadas por sus clientes que les exigían comportarse de la forma descripta en los materiales pornográficos; policías que declaraban que en algunas violaciones el agresor había sido detenido con

autoadscriptiva.

${ }^{4}$ En realidad, bajo el epígrafe «feminismo radical» se hace referencia a un conjunto de grupos que si bien participan de un cierto aire de familia mantienen algunas diferencias entre sí. Que el tema de este trabajo sea analizar la perspectiva de ese movimiento acerca de la pornografia hace que me refiera exclusivamente a determinadas autoras que precisamente han tratado ese tema, a la vez que me excusa que haya dejado de lado conscientemente otras cuestiones. 
material pornográfico en el bolsillo; ex consumidores de pornografía arrepentidos que en el momento 
de la audiencia pertenecían a organizaciones religiosas. Se presentaron testimonios de ex actrices de cine pornográfico como Linda Marchiano (Linda Lovelace, protagonista de la película Garganta Profunda) que narró cómo fue obligada bajo coacción y amenazas a participar en películas pornográficas; y un largo etcétera de supuestas pruebas que buena parte de los expertos no dudó en calificar de «poco fiable» y de «material anecdótico».

En dicha ordenanza se consideraba a la pornografía como una forma de discriminación basada en el sexo, y se la definía como «la gráfica subordinación explícitamente sexual de la mujer por medio de imágenes y / o palabras, y que también incluye uno o más de los supuestos siguientes: I. La mujer es presentada deshumanizada como objeto, cosa o mercancía sexual. II. La mujer es presentada como un objeto sexual que disfruta con el dolor o la humillación. III. La mujer es presentada como objeto sexual que experimenta placer sexual si es violada. IV. La mujer es presentada como un objeto sexual, sea atada, con cortes, mutilada, magullada o con heridas. V. La mujer es presentada en posturas que implican sumisión, servilismo o exhibición sexual. VI. Las partes del cuerpo de la mujer -incluidas aunque no limitadas a la vagina, los senos y las nalgas- son exhibidos de tal manera que la mujer queda reducida a esas partes. VII. La mujer es presentada como una prostituta por naturaleza. VIII. La mujer es presentada siendo penetrada por objetos o animales. IX. La mujer es presentada en contextos que la degradan, la agreden, la torturan y la muestran como un ser sucio o inferior, sangrando, magullada o herida, en un contexto que convierte esas condiciones en algo sexual». Se definía asimismo como pornográfico «el uso de hombres, niños o transexuales en el lugar de la mujer» ${ }^{5}$. Sobre esta ficción jurídica volveré más adelante.

Esta disposición otorgaba cuatro acciones civiles a las supuestas víctimas. Primero, la mujer coaccionada, fraudulentamente inducida o intimidada a realizar actos pornográficos tenía derecho a una acción resarcitoria contra productores, vendedores, exhibidores o distribuidores del material pornográfico. No se considera una excusa absolutoria la prueba ofrecida y producida de que la mujer no haya prestado resistencia, haya cooperado activamente, haya signado un contrato o haya realizado afirmaciones sobre su voluntad de ejecutar acciones pornográficas. Estos actos no precluyen

5 Véase, «The Minneapolis Civil Rights Ordinance, with Feminist Amendment», en Constitutional Commentary, vol. 2, 1985, págs. 181 y ss. Y también Osborne, R., Las mujeres en la encrucijada de la sexualidad. La Sal, 1989, págs. 77 y ss. 
la acción. El consentimiento de la mujer no juega aquí ningún papel. Segundo, si la mujer prueba que existe una relación causal entre el consumo de pornografía y las agresiones sexuales sufridas tiene la posibilidad de iniciar una acción de daño contra el productor, distribuidor y vendedor de dicho material, y no sólo contra su agresor. En los dos casos precedentes se puede solicitar una pena accesoria consistente en la prohibición de futura distribución, exhibición y consumo del material pornográfico. Tercero, la mujer que se viera forzada a consumir pornografía en su lugar de trabajo, en ámbitos educativos, en clubs privados, en el hogar o en cualquier sitio público podrá pedir responsabilidades al agente que lo produce y a la institución de la que se trate. Cuarto, toda mujer, aún cuando no esté incluida en los tres supuestos anteriores, está legitimada en tanto que mujer para actuar contra los materiales que discriminan a las mujeres. Esta última acción tiene por objetivo resarcir el daño cometido a la mujer por el mero tráfico de pornografía.

Considerar la pornografía y su mero tráfico en términos del daño que provoca al estatus de la mujer constituía el núcleo básico de la ordenanza. Se afirmaba, por definición, que la pornografía subordina a la mujer cosificándola y, por ende, transformándola en un objetivo de acoso sexual. Y mientras se señalaba que los hombres, niños o transexuales podrían ser dañados por la pornografía, se enfatizaba que en el caso de las mujeres el daño siempre se produce. Este aspecto de la ordenanza entró en conflicto con las normas que garantizan los derechos civiles. Como es sabido, estas últimas son formuladas en términos neutrales. Prohíben, por ejemplo, la discriminación de cualquier ser humano en virtud de la «raza» o del «sexo», en lugar de hacerlo respecto de un grupo social determinado. «Las diferencias entre los derechos acordados en la ordenanza a hombres y mujeres dio lugar a críticas durante los meses que siguieron a su promulgación, ya que ella misma era discriminatoria y no una medida en favor de los derechos civiles» ${ }^{6}$. Por ese motivo, se cuestionó la compatibilidad de una reivindicación de medidas de censura en base a ese modelo feminista radical con la defensa de los derechos humanos en general y del principio de igualdad en particular.

Convendría, ahora, detenerse un poco en el examen de los detalles de este modelo de disposición antipornográfica. Desde el punto de vista conceptual, la definición de pornografía propuesta

${ }^{6}$ Véase, P. Brest y A. Vandenberg, «Politics, Feminism and the Constitution:...» ob. cit., pág. 620. 
es vaga y ambigua ${ }^{7}$. Este aspecto ya fue señalado por el tribunal de primera instancia que declaró la inconstitucionalidad de la ordenanza. Según su fallo: «las personas sujetas a esta ordenanza no pueden elegir razonablemente entre conductas legales e ilegales, con la confianza de que conocen lo que esos términos (de la ordenanza) significan ${ }^{8}$. Una notificación adecuada de que se ha violado una ley requiere, en un Estado democrático, que esa ley haya sido formulada mediante un lenguaje que respeta el ámbito usual de su significado. Quien lo utilice de una manera distinta tiene la carga de la prueba de que ese uso es claro. La ordenanza no hace ninguna de las dos cosas, y al presentar sus términos con un sentido emotivo-propagandístico sitúa a los ciudadanos en un estado de indefensión, siendo por consiguiente constitucionalmente reprobable. Expresiones como «posición degradante», «posturas de sumisión sexual», «objeto o cosa sexual» o «subordinación sexual» son no sólo difíciles de precisar, sino que, salvo que se tenga una idea preconcebida acerca de su significado, resultan simplemente incomprensibles. Según Raquel Osborne, «para unos la simple representación de un acto sexual sería degradante. Para otros, la degradación sería innegable cuando menos en el caso de la postura del misionero (el hombre encima, la mujer debajo). [Invitar a la penetración] (otro término del proyecto de ley) puede resultar para algunos equivalente a postular la identidad de las mujeres con las prostitutas (las mujeres decentes no solicitan esas cosas); para otros equivaldría en cualquier caso a una práctica machista, ya que el hombre sólo concibe la sexualidad de la penetración... Para ciertas personas, cualquier intento de separar la sexualidad femenina de la procreación, el matrimonio y la familia la convierte en un objeto, al removerla de su lugar y contexto [naturales]...» ${ }^{9}$ Esta definición es asimismo inconveniente porque podría dar lugar a que un anuncio televisivo de un lavavajillas en que aparezca una mujer hablando como ama de casa de las bondades de ese electrodoméstico fuera considerado porno-

${ }^{7}$ Soy consciente que el lenguaje mediante el cual se formulan las normas jurídicas es vago y ambiguo. Expresiones como «agravante por nocturnidad», «cosa»o «hacienda», por ejemplo, poseen esas características. Señalar esos aspectos en la ordenanza podría carecer, en consecuencia, de relevancia. Hacerlo, sin embargo, pone al descubierto los intereses ideológicos y políticos que subyacen a ese tipo (y no a otro) de formulación. Afirmar que los inconvenientes de la definición propuesta por las feministas radicales se debe exclusivamente a las características del lenguaje utilizado es equivocar el análisis.

${ }^{8}$ Citado por Brigman, W., «Pornography as Group Libel: the Indianapolis Sex Discrimination Ordinance», ob cit. pág. 498.

${ }^{9}$ Véase, Osborne, R., Las mujeres en la encrucijada de la sexualidad, ob. cit., págs. 52-53. 
gráfico, si se asume que esa función es sexualmente degradante. En cambio, una película de lesbianismo puro, cuyo principal objetivo sea excitar a la audiencia -y de lograr ese objetivo- mediante la representación de escenas explícitamente sexuales que no dudaríamos en calificarla como pornográfica, podría no constituir un objeto denotado por la definición propuesta si se considera que no degrada a los partícipes. En estos casos, la definición feminista de marras en modo alguno reproduce el uso habitual del término pornografía, ni dada su imprecisión constituye un ejemplo de técnica legislativa adecuada. Pero además, como afirma Joel Feinberg ${ }^{10}$ este tipo de definición no pretende únicamente señalar o aislar a la clase de pornografía más objetable, más ofensiva o más peligrosa para las mujeres, sino que reserva exclusivamente el uso del término «pornografía» a esos casos. Esta redefinición consciente que de ese vocablo realizan muchas feministas es la responsable en buena parte de las confusiones que se producen en el conjunto de las discusiones sobre el tema. «Por tanto, una crítica legítima a la definición de pornografía propuesta no se limitaría sólo a que no da verdadera cuenta de los materiales a los cuales la palabra se aplica de ordinario, sino que constituye una redefinición radical del término. Y una gran porción de los apartados incluidos en el concepto central de pornografía, tal como lo definen Dworkin y MacKinnon, deberían ser considerados más como una reflexión acerca de perversiones patológicas que como materiales que podrían excitar sexualmente a un hombre heterosexual normal» ${ }^{11}$. En este sentido constituye una definición persuasiva dirigida a cambiar la opinión de las personas haciendo que, inconsciente, adhieran a sus posiciones.

Por otra parte, la ordenanza no requiere como condición para la censura que el tema dominante de la obra, considerada como un todo, presente la subordinación de la mujer a través de un material explícitamente sexual. Bastaría que apareciera un único pasaje, sea verbal o gráfico, que sugiera esa subordinación para que toda la obra pueda ser declarada pornográfica $^{12}$. Y al no

${ }^{10}$ Véase J. Feinberg, Offense to Others. Oxford University Press, 1985, pág. 145.

${ }^{11}$ Véase G. Hawkins y F. Zimring, Pornography in a Free Society. Cambridge University Press 1988, pág. 157.

${ }^{12}$ Véase Carr E., «Feminism, Pornography and the First Amendment: An Obscenity-Based Analysis of Proposed Antipornography Laws», en UCLA Law Review, vol. 34, 1987, pág. 1279. La consideración de la obra como un todo es un requisito reconocido por la Suprema Corte a partir del caso Miller vs. United State -1973- para que una determinada obra pueda ser declarada obscena y, por lo tanto, no sujeta a la protección de la Primera Enmienda de la Constitución estadounidense. 
incluir ninguna excepción en virtud del valor literario, científico o artístico de la obra podría dar lugar a la prohibición de la reproducción, distribución, venta, exhibición o consumo de trabajos muy importantes de la literatura universal como el Ulyses de James Joyce, Los trópicos de Henry Miller, El amante de Lady Chatterly de D. Lawrence, La filosofía en el tocador del Marqués de Sade, etc. ${ }^{13}$. La carencia de excepciones de este tipo no es casual. La pornografía -se dice- debido al daño que causa y al negativo impacto que tiene en la vida de las mujeres es considerado un mal en sí mismo (mala in re) y debe, en consecuencia, ser prohibida de una manera absoluta.

«Irónicamente, además, una lectura literal de la ordenanza de Minneápolis podría hacer que los escritos de sus redactores y abogados estuvieran sujetos a persecución por violación de la misma ordenanza que buscaban promulgar. Los escritos feministas de Catharine MacKinnon, Andrea Dworkin y Linda Marchiano, por ejemplo, dan cada uno de ellos una ilustración gráfica y sexualmente explícita de las múltiples maneras en las cuales la pornografía subordina a la mujer. En resumen, partes de estos escritos feministas podrían ser considerados portadores de una subordinación sexualmente explícita, gráficamente descripta en palabras, de mujeres caracterizadas como objetos sexuales deshumanizados, y presentadas en escenarios de degradación, ofensivos, humillación y tortura en contextos que transforman estas condiciones en sexuales» ${ }^{14}$.

Las acciones civiles que otorgaba la ordenanza posibilitaba, por otra parte, que si un único pasaje «pornográfico» de una obra maestra conducía a un lector sicológicamente trastornado a cometer una agresión sexual provocaba que por ese sólo incidente el autor, el editor-productor y el distribuidor de la obra fueran responsables por daños. Y como la pena accesoria era la prohibición de reproducción, distribución y venta de ese material, la acción de ese enajenado podría tener como consecuencia que le fuera vetada el consumo de la obra a la comunidad en su conjunto ${ }^{15}$. Pero si se tomara en serio la pretensión de los autores de la ordenanza habría que censurar casi cualquier material. En

${ }^{13}$ Véase Ronald Dworkin, «Two Concepts of Liberty» en Edana and Avishai Margalit (eds.) Isaiah Berlin. A Celebration. The Hogarth Press, 1991, pág. 103. El mismo articulo bajo el nombre «Liberty and Pornography» en New York Review of Books, 15 de agosto de 1991. En idéntico sentido, Donws, D., The New Politics of Pornography, ob. cit. pág. XXI.

${ }^{14}$ Véase Carr, E., «Feminism, Pornography and the First Amendment», ob. cit. págs. 1279-80.

${ }^{15}$ Idem, pág. 1280 . 
efecto, como ya puse de manifiesto en otro lugar ${ }^{16}$, dentro de un contexto claramente sexual, la lectura del Viejo Testamento condujo a Albert Fish a castrar a niños pequeños para ofrecer sacrificios humanos a Dios. Por ese motivo, Anthony Burgess afirma: «Prohíba el Marqués de Sade y también tendrá que prohibir la Biblia. No más desnudos académicos, no más anuncios de medias, ninguna mujer en las calles de las ciudades (excepto las islámicas cubiertas con sus velos). No Hamlet. No Macbeth.... ${ }^{17}$.

Sobre los peligros que conllevan disposiciones jurídicas con cláusulas semejantes a las de la ordenanza examinada no creo necesario abundar ahora. Sí en cambio me interesa subrayar dos cuestiones. Primero, la intencionalidad represiva absolutamente antiliberal de este modelo, tema sobre el que volveré más adelante. Segundo, el despreciable aparato conceptual utilizado, lo que de alguna manera muestra el estado de indigencia teórica que padece el feminismo radical en general, y que trataré de mostrar en el análisis del próximo apartado.

\section{II}

En cuanto a los aspectos ideológicos que subyacen al modelo de ordenanza anti pornográfica y que forman parte de la concepción del feminismo radical al menos pueden advertirse los siguientes ${ }^{18}$ :

1. El hombre es un ser violento, como violenta es su sexualidad, siendo la pornografía uno de sus agentes causales. Según A. Dworkin, «los hombres aman la muerte. En cualquier cosa que hagan dejan un lugar central para la muerte y permiten que su rancio olor contamine cualquier dimensión de todo aquello que todavía sobrevive. Los hombres aman especialmente el asesinato. En el arte lo celebran, en la vida lo cometen. Los hombres abrazan el asesinato como si la vida sin él estuviera desprovista de pasión, de significado y de acción; como si el asesinato fuera un consuelo que silencia sus sollozos mientras guardan luto por la vacuidad y alienación de sus vidas» ${ }^{19}$. Según esta versión del

${ }^{16}$ Véase Jorge F. Malem Seña, «Acerca de la pornografía» en Revista del Centro de Estudios Constitucionales n. ${ }^{\circ} 11$, enero-abril de 1992, pág. 230.

${ }^{17}$ Véase Burgess, A., «What is Pornography» en Hughes D. Perspectives on Pornography. St. Martin Press, New York 1970, pág. 6.

${ }^{18}$ Para un análisis algo similar, véase: Bryden, D., «Between two Constitutions: Feminism and Pornography», en Constitutional Commentary, vol. 2, 1985, págs. 147 y ss.

${ }^{19}$ Véase A. Dworkin, «Why So-Called Radical Men Love and Need Porno 
feminismo, el hombre, ser depredador y único culpable de la construcción de una sociedad que es definida como sexista, ama la muerte y la violencia. Y deja su impronta letal especialmente en aquel ámbito donde con más fuerza se manifiesta la opresión de las mujeres: el sexual. Algunas feministas radicales han afirmado que, en realidad, lo que el hombre llama «sexo» es una mezcla, en diversos grados, de antagonismo y violencia. Por esa razón, muchas feministas radicales han sostenido que no existe ninguna diferencia entre un coito mutuamente consentido y una violación. Desde esta perspectiva ambos términos son sinónimos ${ }^{20}$.

La pornografía tendría por objeto describir esta forma de violencia. Pero no sólo cumpliría ese papel, sino que incitaría a ella. La provocaría. La pornografía, según C. MacKinnon, «sexualiza la violación, los golpes, las agresiones sexuales, la prostitución y el abuso de los niños, y por lo tanto los celebra, promueve, autoriza y legitima» ${ }^{21}$.

En mi opinión, si lo que el feminismo pretende es afirmar la validez universal de juicios como los precedentes, entonces resultan manifiestamente falsos. La afirmación, por ejemplo, de que el hombre es un ser violento sólo puede ser entendida bajo el supuesto de que la mujer es un ser no violento; y que en el ejercicio de su propia sexualidad no caben la sumisión, las agresiones o las muertes. Sólo así puede entenderse la afirmación de que es biológicamente imposible para la mujer usar la fuerza sexual, esto es, ser superior o dominante $^{22}$. Tal supuesto es, desde un punto de vista empírico, falso. Y utilizado como criterio justificatorio, simplemente, inaceptable. Veamos porqué.

La afirmación de que toda mujer es no violenta se da de bruces con la realidad. Son bien conocidos los ejemplos de mujeres que torturan, que forman parte de bandas terroristas, que agreden y aún matan a sus hijos, etc. Y respecto del delito de violación también resulta bien conocida las acciones de mujeres que, en distintos grados, en él participan, sea en tareas de facilitación,

graphy», en Laura Lederer (comp.) Take Back the Night. William Morrow and Co., New York 1980, pág. 149.

${ }^{20}$ Normalmente, señala Ángela Carter, «las mujeres no fornican, en el sentido activo. Son fornicadas en el sentido pasivo y por lo tanto quedan automáticamente fornicadas, aplastadas, destruidas». Las citas podrían multiplicarse hasta el hartazgo, no creo necesario hacerlo. Véase A. Carter, La mujer sadiana. Versión castellana: Graziela Baravalle. Edhasa 1981, pág. 57.

${ }^{21}$ Véase Catharine MacKinnon, Feminism Unmodified. Harvard University Press 1987, pág. 171.

${ }^{22}$ Véase A. Dworkin, Pornography. Men Possessing Women, A Perigee Books, pág. 134. 
como inductora, sujetando los brazos de la víctima mientras el hombre la accede carnalmente, etc., sin olvidar por cierto que después de la reforma del código penal español del año 1989 la mujer puede perfectamente ser sujeto activo de ese delito que tradicionalmente fue definido como masculino. Lo narrado es suficiente para mostrar que el ser humano, sea hombre o mujer, es capaz de cometer actos violentos injustificados contra terceros, y que cualquier afirmación general acerca de supuestos comportamientos pacíficos de todos los miembros de un sexo, por el mero hecho de su pertenencia a ese sexo -y al margen de cómo se comportan realmente-, resulta empíricamente falsa. Lo cual, naturalmente, no es poco.

Pero si la afirmación de que el hombre es violento y la mujer no violenta no hace referencia ya a cuestiones empíricas -falsas-, sino a una supuesta «naturaleza» que determina cómo deberían ser los sexos surgen entonces problemas lógicos e ideológicos. En efecto, mientras algunas feministas consideran la naturaleza femenina como tierna, abnegada, protectora, pacífica e igualitaria, «se contempla la violencia masculina como algo intrínseco y como cristalización de la masculinidad $»^{23}$.

Ahora bien, cuando las feministas radicales utilizan la expresión «naturaleza del hombre, mujer» lo hacen con un claro sentido normativo. Pero obrando de esa manera se puede querer afirmar dos cuestiones distintas, tal como ha puesto de manifiesto Ernesto Garzón Valdés respecto de la llamada «naturaleza de las cosas» ${ }^{24}$. Si lo que se pretende con la apelación a la «naturaleza» es derivar juicios de deber ser a partir de situaciones de hecho de hombres y mujeres, se viola un principio lógico incurriendo en la llamada falacia naturalista. Si lo que en cambio se hace es presuponer ciertas premisas normativas que se adscriben a determinados comportamientos (que la sexualidad masculina es, por ejemplo, negativamente violenta; o que la penetración que se produce en el acto sexual es una agresión indebida) definiendo los valores positivos como femeninos y los masculinos como negativos, entonces se realizan procedimientos entimemáticos. Aquí el error no es de tipo lógico, pero existe un preconcepto ideológico arbitrario y no explicitado. En cualquier caso, ambas hipótesis son rechazables.

Y el problema no se resuelve en favor de la tesis de las feministas radicales ni aún

${ }^{23}$ Véase Echols, A., «El ello domado: la política sexual feminista entre 1969-83», ob. cit. pág. 85.

${ }^{24}$ Véase Garzón Valdés, E., Derecho y «naturaleza de las cosas», T. II. Universidad Nacional de Córdoba -RA-. 1971, especialmente págs. 81 y ss. 
en el caso que se acepte que la supuesta 
violencia masculina no se debe a ninguna «esencia», sino que es fruto de una construcción social. Según Frances Olsen, comprender este punto es importante. El sexo no sería ya un dato pre social, inmodificable. «El sexo es universal, aunque también es históricamente específico y nuestra sociedad ha construido una sexualidad que a menudo está vinculada a la violencia. Si la relación de dominación y subordinación es sexual, la erotización de la violencia se transforma precisamente en un caso de la erotización de la dominación y subordinación ${ }^{25}$. Pero nuevamente aquí aparecen los mismos inconvenientes que justamente se querían evitar. ¿Qué significa que la violencia masculina resulta de una construcción social?, ¿acaso que todos los hombres se comportan empíricamente de una manera violenta mientras ninguna mujer actúa de esa manera?, ¿puede explicarse y justificarse -o no- el supuesto comportamiento de una clase -la de los hombres- al margen de las acciones de todos y cada uno de sus miembros? Creo que no.

En realidad, la construcción del modelo del feminismo radical basado en la dualidad masculino-femenino, violento-no violento se muestra incapaz de servir como esquema explicativo de la realidad; a la vez que muestra sus miserias ideológicas enmascaradoras. Dentro de ese esquema es imposible encontrar contra ejemplos. Si algún hombre concreto es violento habrá validado el modelo, si no lo es, en cambio, se habrá comportado como una mujer, lo que asimismo validará el modelo. Y lo mismo sucede respecto de las féminas. Cualquier comportamiento, de cualquier individuo servirá, pues, para otorgar validez al esquema propuesto. Hablando del Marqués de Sade, Ángela Carter lo expresa de una manera categórica: «dentro de este esquema, macho significa tirano y hembra, víctima, sean cuales sean los sexos oficiales de las personas ${ }^{26}$. Ahora bien, un esquema explicativo ha de estar compuesto de una hipótesis o de un conjunto de hipótesis. Pero si por definición no puede haber ningún caso que las falsee, entonces tal esquema resulta inútil, ya que, en definitiva, no sirve para explicar ningún caso. De todas maneras, ya se sabe: «los hombres aman la muerte...».

Por otra parte, tampoco queda claro en qué sentido se usa el término «violencia». Las feministas radicales han extendido tanto el ámbito de su significación que casi cualquier acción puede ser por él denotado. La utilización de términos con fuerte carga emotiva más allá de los límites de los cuales pueden ser usados

${ }^{25}$ Véase Olsen, F., «Feminist Theory in Grand Style», en Columbia Law Review, vol. 89, n. ${ }^{\circ}$ 5, junio 1989, pág. 1156.

${ }^{26}$ Véase Carter, A., La mujer sadiana, ob. cit. pág. 34. 
informativamente o como criterio justificatorio puede advertirse también en el uso que de la palabra «coerción» se hace en el modelo de disposición antipornográfica propuesto por A. Dworkin y C. MacKinnon. En efecto, redujeron tanto la intensión de las voces «violencia»y «coerción» que las hicieron perfectamente compatibles con el consentimiento que las personas podrían hipotéticamente llegar a prestar. De ese modo, se hace posible que una mujer, por ejemplo, pueda ser «violentada» o «coercionada» mediante actos a los cuales prestó su libre consentimiento. Esto explica la razón del porqué en la ordenanza examinada incluso una mujer que haya firmado un contrato válido para realizar una película pornográfica seguía poseyendo la acción por daños. Pero sostener la tesis de la compatibilidad del consentimiento con la coerción o la violencia no sólo constituye una contradicción en los términos, sino que destruye cualquier parámetro jurídico y hasta moral. Cualquier acción podría ser «violenta» o «coaccionadora» a condición de que el juzgador -las feministas radicales en este caso- así lo establecieran. Y como el libre consentimiento prestado por la supuesta víctima resulta inválido como excusa o justificación el grado de indefensión del supuesto agente de la supuesta violencia es total. Y si desde un punto de vista jurídico tal esquema resulta, en las democracias, claramente inconstitucional, desde el punto de vista ético es manifiestamente inaceptable ${ }^{27}$.

Por lo demás, la creencia que la pornografía incita a la comisión de actos violentos carece de base justificada. Sobre este aspecto volveré más adelante.

2. Existe una ideología de la supremacía masculina. La pornografía constituye su explicitación. Según el feminismo radical existiría una ideología cuya función principal consistiría en diseñar y legitimar un contexto social general de supremacía masculina. $\mathrm{Su}$ primer dogma es la afirmación metafísica de la identidad dominante del hombre. Expresa su autoridad intrínseca, la cual no puede ser reducida o erradicada. Y para asegurar esta ideología el hombre utiliza su fuerza física, su potencialidad para imponer el terror, su dinero y su capacidad para nombrar, es decir, para generar un lenguaje y un esquema conceptual cuyo único fin es mantener la subordinación femenina. La pornografía no hace sino coadyuvar al diseño y mantenimiento de ese esquema opresivo. Según A. Dworkin, «La evaluación de la mujer en la pornografía es un tema secundario en que su degradación existe con el objeto

${ }^{27}$ Naturalmente, esta afirmación supone una cierta concepción del daño, de la posibilidad que un individuo se dañe a sí mismo y del consentimiento. Tema que se abordará en el apartado tercero de este trabajo. 
de postular, ejercitar y celebrar el poder masculino. Poder masculino que al degradar a la mujer está primero interesado en sí mismo, en su perpetuación, expansión, intensificación y elevación $»^{28}$. No es de extrañar, pues, que Susan Brownmiller afirme: «la pornografía, como la violación, es una invención masculina dirigida a deshumanizar a la mujer para reducirla a un objeto de acceso sexual y no a liberar su sensualidad de inhibiciones familiares o moralistas... La pornografía representa la esencia pura de la propaganda contra la mujer» ${ }^{29}$. Para cumplir con el objetivo de afianzar la ideología masculina, siempre según esta versión, la pornografía miente acerca de la mujer, de su sexualidad y de sus verdaderos intereses. En palabras de Helen Longino, «La pornografía miente cuando dice que nuestra vida sexual es o debe estar subordinada al servicio del hombre, que nuestro placer consiste en darle placer a los hombres y no a nosotras mismas, que somos depravadas, y que estamos dispuestas a ser objeto de violación, esclavitud, tortura y asesinato. La pornografía mienta explícitamente acerca de la sexualidad de la mujer, y a través de tales mentiras fomenta aún más mentiras acerca de nuestra humanidad, nuestra dignidad y nuestra personalidad $»^{30}$.

El hombre necesitaría la clase de mentiras expuestas en la pornografía en un intento desesperado de preservar su yo, su propia sexualidad y su posición dominante ${ }^{31}$. La propaganda sería el medio idóneo para hacer públicas y creíbles esas mentiras. En la pornografía se perseguiría imponer los estereotipos sexuales vigentes regidos por la relación dominación-subordinación. Por medio de la propaganda pornográfica los hombres y las mujeres serían dibujados como seres diametralmente opuestos, a menudo como enemigos. $\mathrm{Y}$ al seleccionar sólo una parte de la sexualidad de la mujer -la genital- la mostrarían al servicio del hombre, desposeyéndola de su propia naturaleza, de su propia esencia. La consecuencia de todo ello es que los papeles de dominación y subordinación sociales se ven reforzados, a la vez que se reproduce el esquema sexual vigente. La pornografía sería, pues, una forma de perpetuar el status quo. Beverly LaBelle lo expone con meridiana claridad, «Disimulada bajo su fachada de entretenimiento sexual-

${ }^{28}$ Véase A. Dworkin, Men Possessing Women, ob. cit. págs. 24-25.

${ }^{29}$ Véase Susan Brownmiller, Against our Will. Bantan Books. New York 1990, pág. 443.

${ }^{30}$ Véase Longino, H., «Pornography, Oppression and Freedom: A Closer Look», ob. cit. pág. 46.

${ }^{31}$ Véase Lurie, S., «Pornography and the Dread of Women: The Male Sexual Dilemma» en Lederer L. (ed.) Take Back the Night, ob. cit. pág. 160. 
mente liberado, la pornografía propaga la filosofía de la supremacía masculina. Establece ideológicamente que la mujer existe sólo para la gratificación sexual del hombre. Debido a que tales ideas deshumanizadoras de la mujer son tan ampliamente aceptadas, no se reconoce a menudo a la pornografía como un sistema de propaganda diseñada para explotar y tergiversar las diferencias sexuales entre hombres y mujeres... La pornografía es la propaganda de la misoginia ${ }^{32}$.

Creo, sin embargo, que un análisis detallado de estas afirmaciones basta para mostrar algunas imprecisiones conceptuales, ciertas falsedades de carácter empírico y errores varios en la argumentación. En primer lugar, aún cuando se admita que la pornografía muestra a las mujeres como seres cuya sexualidad ponen al servicio del placer del hombre no significa por cierto que las describan, sin más, en términos «degradantes». Si tal fuera el caso, serían representadas de manera laudatoria, como amantes consideradas, siempre prestas a ejecutar comportamientos supererogatorios. Al poner voluntariamente toda su potencialidad en favor del «otro», sin importarles su propio goce, realizarían las acciones típicas de una santa o de una heroína. De este modo, si se acepta que, en este caso, la pornografía miente acerca de la sexualidad de la mujer, no se debe aceptar que la difama, la degrada o la daña, ya que su mensaje sería éticamente positivo -supererogatorio- ${ }^{33}$.

Además, podrían encontrarse materiales pornográficos que crecieran de representaciones femeninas; o aún más, materiales que representaran un hombre de tendencias masoquistas «humillado» $\mathrm{y}$ «dominado» por una amazona de portentosas dimensiones. Estos materiales no serían, ni podrían ser, de acuerdo a la definición aquí examinada, degradantes para la mujer ${ }^{34}$.

Tampoco puede aceptarse las tesis feministas precedentes y decir a continuación que las mujeres son mostradas en la pornografía violadas, maltratadas o golpeadas para vencer su resistencia -recuérdese los términos de la ordenanza de Indeanapolis-, ni puede aceptarse que la pornografía miente igualmente porque muestra a la mujer preocupada sólo por su goce sexual, tal como lo hacen, Susan Griffin y concordantemente con ella el Papa Carol Wojtyla ${ }^{35}$. O la pornografía miente en un sentido, o lo hace

${ }^{32}$ Véase LaBelle, B., «The Propaganda of Misogyny», en Lederer: (ed.) Take Back the Night, ob. cit. pág. 178 .

${ }^{33}$ Véase Soble, A., «Pornography: Defamation and the Endorsement of Degradation», en Social Theory and Practice, vol. 11, n. ${ }^{\circ} 1,1985$, pág. 64.

${ }^{34}$ Véase J. Feinberg, Offense to Others, ob. cit. pág. 145.

${ }^{35}$ Citados por A. Soble, idem págs. 65 y 63 respectivamente. 
en un sentido contrario, no en ambos a la vez. Pero de las múltiples contradicciones del feminismo radical no me haré cargo ahora.

En realidad, este tipo de contradicciones está motivada como señala Alan Soble porque se considera el mensaje pornográfico como claramente proposicional ${ }^{36}$. Pero ello constituye un error. La pornografía no está interesada en describir realidad alguna, ni en formular hipótesis acerca de la sexualidad, ni en esgrimir tesis explicativas del mundo. Su objetivo es más simple: lograr la excitación sexual de su audiencia. Para ello se apela a la fantasía del consumidor. De ser así, a nadie se subordina, a nadie se explota, a nadie se daña. Como tampoco lo hace una novela de ciencia ficción o un cuento de ladrones y policías $^{37}$.

Además, la afirmación que la pornografía es sólo una cuestión de hombres es empírica, cuya falsedad es manifiesta si se piensa que algunos de los últimos grandes éxitos editoriales pornográficos fueron escritos por mujeres, que en las grandes ciudades existen espectáculos pornográficos dirigidos exclusivamente a mujeres y que buena parte de los consumidores de cintas de vídeo pornográfico son mujeres. Y tal afirmación resulta peligrosa porque cierra un camino donde las mujeres pueden encontrar una nueva fuente del placer. Según Carole Vance, «es muy fácil avergonzar a las mujeres con respecto a lo sexual, y el movimiento antipornografía hace posibles nuevas formas de avergonzarlas. Las afirmaciones tradicionales de que el interés de las mujeres por lo sexual no es importante se vuelven a presentar cuando se apunta que la sexualidad es trivial, que distrae de los objetivos fundamentales o que no es política. Si se codifica el deseo sexual como masculino, las mujeres empezarán a preguntarse si alguna vez son de verdad seres sexuales ${ }^{38}$.

Por otra parte, en los Estados democráticos existen constituciones que rechazan abiertamente cualquier discriminación en razón del sexo como ilegítima. La ideología emergente del libera-

${ }^{36}$ Idem, pág. 66.

${ }^{37}$ La noción de «mentira» puede ser establecida en términos de condiciones necesarias y suficientes. Para que un enunciado pueda ser calificado de «mentira» ha de ser, en primer lugar, falso. Para que ello sea posible el uso del lenguaje utilizado ha de ser descriptivo. En segundo lugar, quien formula el enunciado, «el agente mentiroso», debe conocer que su mensaje es falso y lo oculta a sabiendas. Ninguno de estos dos aspectos concurren en el fenómeno pornográfico. Afirmar que la pornografía miente acerca de la mujer es conceptualmente inconsistente.

${ }^{38}$ Véase C. Vance, «El placer y el peligro: hacia una política de la sexualidad» en Carlo S. Vance (comp.) Placer y peligro. Versión castellana Julio Velázquez, Ed. Revolución 1989, pág. 18. 
lismo moral que subyace a estas constituciones proclama como uno de sus dogmas más queridos el de la igualdad de derechos entre hombres y mujeres. Sería ocioso decir que entre quienes abrazan este liberalismo moral abogando, por tanto, por la igualdad entre las personas existen numerosos seres humanos del sexo masculino. Que todos los hombres asuman siempre una ideología machista es, pues, empíricamente falso. Señalar que la pornografía reafirma la ideología machista que todo hombre tiene es, sencillamente, inaceptable.

3. En esta sociedad dominada por el varón impera el sadismo cultural. La noción de sadismo cultural hace referencia, según Kathleen Barry, «al conjunto de las prácticas sociales que favorecen y propugnan la violencia sexual, incorporándola a la noción de lo que se define como comportamiento normal. Estas prácticas aparecen integradas en el tejido cultural y, en este sentido, el sadismo cultural tiene su propia evolución histórica y cuenta con una ideología de apoyo que lo legitima y lo justifica» ${ }^{39}$.

La violencia sádica y la esclavización sexual de la mujer no serían fenómenos remotos o aislados. Son propios de nuestras sociedades, están presentes en el vivir cotidiano, y alcanzan su última expresión en el poder masculino de conquista. Según A. Dworkin, «los hombres cazan a las mujeres, las capturan, las atan, las engullen y las montan. Lo excitante está precisamente en el carácter no consensual del evento... El poder del sexo, en términos masculinos, es también funerario. La muerte lo permite. La trinidad erótica masculina -sexo, violencia y muerte- reina absolutamente. La mujer es o será muerta. Ellos la asesinan o la asesinarán. Cualquier cosa que ellos hagan será violencia $»^{40}$.

En tal sociedad, se iría perdiendo paulatinamente la distinción entre amor y violencia, entre sexo consensuado e impuesto. Se impondría un clima adecuado para la vejación de la mujer. Los golpes, las agresiones y la violación quedarían justificadas culturalmente y se perdería la separación entre mujeres «decentes» e «indecentes». Las formas concretas en que se manifiesta este sadismo cultural son amplísimas. Van desde el lupanar masculino local hasta los viajes programados de turismo sexual. Desde la posibilidad de ejecutar acciones degradantes contra las mujeres si se realizan en privado, a la compra del sometimiento físico a través de la prostitución o, según ciertas legislaciones, del matri-

${ }^{39}$ Véase K. Barry, Esclavitud sexual de la mujer. Versión castellana: Paloma Villegas y Mireia Bofill. Editorial La Sal 1987, pág. 225.

${ }^{40}$ Véase A. Dworkin, Pornography. Men Possessing Woman, ob. cit. pág. 30. 
monio. La pornografía sería una manifestación práctica más del sadismo cultural. Difundiría cuáles son las prácticas sexuales aceptadas y, por tanto, posibles de ser impuestas en las vidas privadas de las personas. La pornografía «ya no describe únicamente las actividades sexuales que se desarrollan entre las prostitutas y sus clientes. La liberación sexual ha introducido en los hogares muchas de las extravagancias sexuales que los hombres tradicionalmente exigían de las prostitutas. La pornografía no describe sólo lo que puede hacerse con una prostituta, sino también con la amante, la esposa o incluso con la propia hija. A través de la pornografía comienzan a hacerse borrosas las distinciones consagradas por la sociedad y se va colmando rápidamente la brecha entre amor y violencia, entre mujeres [puras] y prostitutas ${ }^{41}$. Y el tema básico de esta forma de representación sería el absoluto menosprecio de las mujeres, «en una filmación tras otra, las mujeres son violadas, cubiertas de esperma y de orina, penetradas analmente, golpeadas y, en una nueva modalidad en ascenso, asesinadas en medio de una orgía de placer sexual $»^{42}$.

Es claro que esta reconstrucción de las relaciones sexuales imperantes en nuestras sociedades y de la función que cumple la pornografía es altamente exagerada, cuando no manifiestamente falsa. En la mayoría de los países de nuestro entorno cultural -y en España de una manera específica- las agresiones sexuales están severamente castigadas, tanto si se producen dentro como fuera del matrimonio, en público y en privado. Las constituciones receptan en su seno normas antidiscriminatorias e imponen el respeto a la dignidad y a la autonomía de las personas. Soy consciente que este argumento en modo alguno convencerá a quien se sienta identificado con la tesis del feminismo radical. «Nuestras luchas -dice Kathleen Barry- amenazan los valores sexuales promovidos por la ideología masculina. Al hacerlo, nos enfrentamos al doble parámetro sexista que, mientras condena jurídicamente los actos de violencia sexual, en los hechos los valida ideológicamente en los medios de comunicación tales como la pornografía» ${ }^{43}$.

Pero razonamientos de este tipo implican generalizaciones falsas por una parte, $y$, por la otra, argumentaciones circulares de nulo valor explicativo. Generalizaciones falsas porque, como se mostró en el apartado anterior, no es admisible, sin más, la

${ }^{41}$ Véase Barry, K., Esclavitud sexual de la mujer, ob. cit. pág. 224.

${ }^{42}$ Idem, pág. 225.

${ }^{43}$ Véase Barry, K., «Beyond Pornography: From Defensive Politics to Creating a Vision», en Lederer, L. (ed.) Take Back the Night, ob. cit. pág. 308. 
existencia de una ideología masculina sustentada por todo el colectivo de hombres cuya única misión sea la subordinación de la mujer y cuya expresión práctica sea la violencia sexual. Y que se generalice que la pornografía describa y promueva las acciones propias del sadismo cultural no responde a la realidad. De todos los materiales pornográficos examinados por la Comisión Meese, por ejemplo, sólo el uno por ciento contenía escenas violentas, mientras en la industria se sostiene que tiene esa característica incluso un porcentaje inferior.

La percepción que la pornografía es una representación que está firmemente interesada en la dominación y subordinación de la mujer por medio de la violencia es inadecuada y está basada en una percepción selectiva. "Como una cuestión de definición, las escenas de violación y de violencia contra las mujeres son relativamente raras en los cines pornográficos de audiencia masiva: las películas pornográficas describen a hombres y mujeres dominados por la lujuria, lo que tiene como resultado que no hay resistencia a las propuestas sexuales. Un análisis reciente del contenido de 67 películas pornográficas en Nueva York, Houston y Austin encontró muy poco (menos del uno por ciento del total del tiempo filmado) sadomasoquismo o violencia. En su lugar, el estudio encontró que probablemente los hombres están más sujetos a tales violencias que las mujeres. Basado en estos datos, es discutible la tesis de que las mujeres son, en la pornografía, rutinariamente brutalizadas; esa tesis es, al menos, sesgada ${ }^{44}$.

A la circularidad del modo de razonar del feminismo radical ya se hizo referencia también con anterioridad. Si se prueba que un hombre comete aquellos actos violentos propios del sadismo cultural sus afirmaciones quedan contrastadas. Si se comprueba, en cambio, la vigencia de la legislación y prácticas sociales antidiscriminatorias se trata de un ejercicio de doble moral. Todo vale para sostener la tesis de la demonización de lo masculino. En concordancia con esa tesis, el feminismo radical afirma que el Estado democrático es un instrumento de dominación de la mujer.

4. El Estado democrático y su derecho está diseñado para acallar y subordinar a la mujer. La pornografía silencia a la mujer mientras enseña a los hombres cómo deben tratarlas.

Como se sabe el Juez del Distrito que sancionó la inconstitucionalidad de la ordenanza de Indianápolis adujo que ésta violaba la Primera Enmienda de la Constitución de los EE.UU. que garantiza la libertad negativa a la libertad de expresión. En opinión del juez Eastebrook no se puede prohibir un material que única-

${ }^{44}$ Véase Brigman, W., «Pornography as Group Libel:... ob. cit. pág. 495. 
mente refleja una opinión en la cual las mujeres pueden aparecer sometidas o dominadas. No puede prohibirse un «speech» por malo que sea su mensaje sin destruir el principio a la libertad de expresión.

Pero desde una perspectiva feminista, las consideraciones precedentes resultan intolerables. En opinión de K. MacKinnon, cuando la pornografía es defendida en el nombre de la libertad de expresión se lo hace acallando a mujeres y niños, sobre cuyo silencio el derecho, incluyendo la Primera Enmienda, fue construido.

Según esta versión, la cláusula de libertad de expresión en la Constitución estadounidense fue impuesta por hombres blancos que eran propietarios de esclavos, por hombres que eran propietarios de mujeres. Cumplieron su objetivo de salvaguardar esa libertad de cualquier ingerencia estatal, pero a costa de silenciar a las mujeres. «Observando la constitución a través de la lente del feminismo, -dice K. MacKinnon- se ve inicialmente la exclusión de las mujeres de la Constitución. Esto es decir simplemente que nosotras no tenemos ninguna voz en el documento constitutivo del Estado ${ }^{45}$.

Las constituciones, en general y no sólo la norteamericana, se interpretarían como algo estructurado alrededor de lo público. Ello significa que las garantías para la libertad de los ciudadanos comienza donde empieza el derecho. Esta tesis es exaltada -continúa la feminista americana- como [libertad negativa] y constituye la piedra angular del Estado liberal. Pero una interpretación liberal de la Primera Enmienda se mueve dentro de un nivel abstracto y fracasa al no tomar en consideración el daño concreto en forma de expresión infringidos a los grupos sin poder. La posición absolutista de la interpretación de la Primera Enmienda de la constitución estadounidense según la cual existe un igual interés en el mercado de las ideas es falso respecto de las mujeres. «En primer lugar, porque el mercado de las ideas es literal: aquellos con más dinero para gastar más pueden hablar, y las mujeres son pobres. Segundo, proteger a los pornógrafos, como ahora lo hace la primera Enmienda, no promueve la libertad de expresión de las mujeres. No lo hace. La pornografía no está en función de nuestra libertad de expresión. Como mujer, no tenemos en el sistema existente el nivel que dicen que tenemos» ${ }^{46}$. Subrayar este aspecto es importante porque a juicio de las feministas las mujeres son oprimidas socialmente, a menudo en con-

${ }^{45}$ Véase K. MacKinnon, Feminism Unmodified, ob. cit. pág. 206.

${ }^{46}$ Idem pág. 140. 
textos íntimos y no sólo públicamente. La estructura jurídico política que permite que en contextos no públicos se someta a la mujer provocaría que precisamente aquellos ámbitos donde la mujer más subordinada se viera serían asumidos por la Constitución como el reino de la libertad. La democracia, arguye K. Barry, «establece un entorno pluralista favorable para la proliferación de la ideología del sadismo cultural. La diversidad de las perversiones sexuales encaja perfectamente con la noción pluralista de la diversidad cultural y queda reducida a la expresión coloquial [sobre gustos no hay nada escrito]. Nadie debería cuestionar ni preocuparse por cómo cada uno intenta satisfacer sus necesidades sexuales. Nuestra sociedad garantiza el derecho a la libertad de expresión, y la pornografía, se argumenta, no hace daño a nadie más, de modo que si un tipo la quiere, debe dársele lo que desea» ${ }^{47}$.

Pero estas afirmaciones resultan implausibles. Es algo reconocido en el ámbito constitucional que lo garantizado por las cláusulas de libertad de expresión es permitir el intercambio de ideas, aún cuando de éste se puedan derivar consecuencias negativas. Según Ronald Dworkin, «la libertad de expresión, concebida y protegida como una libertad negativa fundamental, es el núcleo de la elección que han realizado las democracias modernas, una elección que nos obliga a encontrar nuestra propia manera de combatir incluso las vergonzosas desigualdades que padecen las mujeres ${ }^{48}$. De este modo el derecho aparecería también respecto de las mujeres como un elemento activo en la consecución de objetivos de libertad e igualdad para todos, y no como un mero instrumento de dominación.

Por otra parte, aun cuando se acepte que la libertad de expresión en sentido negativo sea una garantía contra la ingerencia estatal que puede ser esgrimida sólo en ámbitos públicos no se sigue que sea el instrumento por el cual se silencia a las mujeres. Las propias propuestas de A. Dworkin y K. MacKinnon, sus libros y sus numerosas intervenciones en diferentes escenarios de la vida pública plagadas de falsedades empíricas, errores argumentativos y de ataques contra la democracia muestran hasta qué punto no han sido como mujer acalladas y hasta qué punto sus propias afirmaciones resultan desmentidas por sus propias acciones. La asimilación que se pretende hacer, según Ronald Dworkin, del supuesto silencio impuesto a las mujeres en la pornografía a la producción de un alboroto o de un ruido ensordecedor que se

${ }^{47}$ Véase K. Barry, Esclavitud sexual de la mujer, ob. cit. pág. 271.

${ }^{48}$ Véase R. Dworkin, «Two Concepts of Liberty», ob. cit. pág. 107. 
realiza para acallar a los participantes en una asamblea es propia de quien sufre una confusión conceptual. «No hay contradicción en sostener que una idea debe poder ser oída, aun si tiene como consecuencia que otras ideas sean mal comprendidas, o minusvaloradas, o imposibles de expresar porque quienes son susceptibles de defenderlas no tienen ningún dominio sobre su propia imagen pública y no pueden en consecuencia ser comprendidas como lo desean. Son consecuencias muy nefastas, y es necesario luchar contra ellas tanto como la Constitución lo permita. Pero estas actitudes no pueden llegar a privar a los individuos de su libertad de expresión ${ }^{49}$.

La implausibilidad de las tesis radicales también se pone de manifiesto cuando se sostiene que la libertad de expresión conduce, utilizada como manto protector de la pornografía, a la degradación de la mujer. Como ya fue señalado, la pornografía homosexual carece de representaciones femeninas. En esos casos difícilmente se puede degradar la posición de la mujer. Cuando la Ordenanza de Indianápolis definía como pornográfico el uso de hombres, niños y transexuales en el lugar de la mujer y asimilaba el papel de estos niños y hombres al de la mujer creaba una ficción que muestra hasta qué punto se partía de pre-concepciones acerca de los valores que imbuyen la sexualidad en general, el acto sexual en particular y que determinan la definición de subordinación. La adscripción de papeles, funciones y valores sexuales aparece aquí de una forma totalmente arbitraria, reflejo fiel de estereotipos infundados de comportamientos.

Es claro que el feminismo radical se muestra encorsetado bajo estereotipos sexuales de «normalidad» rígidamente definidos, fuera de los cuales campean las perversiones más denigrantes. Se pretende ignorar que los intercursos y prácticas sexuales pueden realizarse de muy diferentes maneras, todas ellas satisfactorias para los intervinientes si se comprende la naturaleza del acto en cuestión y se consiente a llevarlo a cabo. La imposición de patrones inflexibles de comportamientos sexuales definidos como correctos que nieguen la realización de otros alternativos, aun cuando éstos no dañen a nadie, conduce a un perfeccionismo moral éticamente inaceptable.

Finalmente, la acusación que la pornografía construye la representación social de la mujer, a la vez que genera pautas de comportamiento masculino que los hombres no dudan en seguir constituye otra constante en el pensamiento feminista radical. Según Catherine Itzen, «la pornografía... comunica inexorablemente: esto es lo que son las mujeres, esto es lo que quieren y esto

${ }^{49}$ Véase R. Dworkin, «Two Concepts of Liberty», ob. cit. pág. 108. 
es lo que está permitido hacerles. En y a través de la pornografía los hombres enseñan cómo tratar a las mujeres y entonces éstas son subordinadas en la sociedad sexual, social y económicamente» ${ }^{50}$.

Aquí el argumento nuevamente es de tipo causal. No se dice que la pornografía sea el síntoma, la consecuencia o el símbolo de la reconstrucción social de la imagen de la mujer, sino que es la causa de esa imagen. Es obvio, no obstante, que puede pensarse en una sociedad que carezca de representaciones explícitamente sexuales y que proyecte, pese a ello, una imagen de la mujer «degradada» o «dominada por el hombre» a través del sistema educativo o laboral. Bajo ese supuesto, no podría achacarse a la pornografía ser la causa de la distorsión de la imagen de la mujer; y, por cierto, por esa razón, su eliminación de la sociedad actual no garantizaría que esa supuesta imagen desapareciera. «El ataque a la pornografía como portadora de valores sexistas, valores que se extienden a la literatura, los anuncios comerciales, los entretenimientos y, desde este punto de vista, a la mayoría de los aspectos de la existencia social parecen justificarse simplemente sobre la base de que [algunas cosas son peores que otras]. Pero aunque esta proposición es indiscutible, en este sentido la pornografía no es más que un síntoma, algo que acompaña e indica la existencia de una condición patológica subyacente. Y aunque puede juzgarse más distorsionante, más descarada o más repugnante que algunos de los otros síntomas, no hay razón para creer que su supresión curará la enfermedad. Además, la medicina prescripta parece tener efectos secundarios probadamente indeseables, verdaderamente inaceptables, y no sólo para los consumidores masculinos, sino para todos los ciudadanos» ${ }^{51}$. La identificación de «causas» con «síntomas» constituye una muestra más de la debilidad teórica del feminismo radical. Y van...

Las acusaciones del feminismo radical precedentes tampoco pueden mantenerse en virtud de sus propios méritos si se toma en consideración, sobre todo, la extremada abstracción de la estructura pornográfica. Según Román Gubern, «a pesar de las acusaciones lanzadas contra el porno por el hiperrealismo de las acciones mostradas en la pantalla, el que sus personajes descontextualicen su actividad sexual de la vida afectiva y de sus roles e interacciones sociales empuja al género al campo de la pura abstracción, de la

$12-13$.

${ }^{50}$ Véase C. Itzen, «Pornography and Civil Liberties». Index on Censorship, 9/1990, págs.

${ }^{51}$ Véase G. Hawkins y F. Zimring, Pornography in a Free Society, ob. cit. pág. 172. 
pura irrealidad, del esquematismo» ${ }^{52}$. Concordantemente con ello, Ángela Carter afirma: «Dado que toda pornografía se deriva directamente del mito, se deduce que todos sus héroes y heroínas, desde el más grosero al más complejo, son abstracciones míticas, héroes y heroínas dotados de dimensión y volumen. Cualquier destello de hombre o de mujer real está ausente de estas representaciones del macho y la hembra arquetípicos».

«La naturaleza de lo individual no se resuelve en esos arquetipos, sino que es ignorada por ellos, ya que la función del arquetipo es disminuir el Yo único a favor de un ser sexuado colectivo que, a causa de su propia naturaleza, no puede existir como tal, porque un arquetipo, sólo es una imagen que se ha extendido más allá de su significación originaria y engendra, en el mejor de los casos, una relación fantasiosa con la realidad ${ }^{53}$. Si tal es el caso, la estructura pornográfica estaría recubierta por un manto de falsedad e incredibilidad que torna imposible la construcción de la imagen de la mujer y, mucho menos, un modelo a seguir.

Hay que subrayar, asimismo, que la pornografía no tiene una presencia generalizada en nuestras sociedades, y que se puede pasear cotidianamente por el mundo sin tropezarse con ella. Además, como ya expresé en otro $\operatorname{lugar}^{54}$ aun cuando se admita que un material determinado degrada a una mujer determinada, no se infiere lógicamente que ese material degrade al conjunto de todas las mujeres del planeta. Del mismo modo que la sustracción de un radio cassette de un automóvil no implica un ataque a todos los automovilistas propietarios de radio cassette. Habría en quien sostuviera una posición semejante una falacia en la composición.

5. La pornografía no sólo es mala in re, es la causa de la comisión de delitos sexuales violentos. El argumento es simple. A una mayor disponibilidad de pornografía en el mercado le sigue un incremento considerable de ataques sexuales contra las mujeres. La pornografía causaría delitos tales como la violación, los abusos deshonestos, las mutilaciones rituales y, en algunos casos, hasta el asesinato. Como he tratado este tema en algún detalle con anterioridad ${ }^{55}$, no creo necesario reproducir los argumentos ahora. Basta decir que no existen pruebas empíricas concluyentes que avalen esa pretendida relación

${ }^{52}$ Véase Román Gubern, La imagen pornográfica y otras perversiones ópticas. Akal/ Comunicación. Madrid 1989, pág. 12.

${ }^{53}$ Véase A. Carter, La mujer sadiana, ob. cit. pág. 14.

${ }^{54}$ Véase Jorge F. Malem Seña, «Acerca de la pornografía», ob. cit. pág. 231.

${ }^{55}$ Idem, págs. 229 y ss. 
causal. Ni los estudios realizados permiten inferir indubitablemente tales conclusiones. 
El modelo de ordenanza analizado como así también los presupuestos que a ella subyacen muestran claramente cuál es la concepción del feminismo radical respecto de la pornografía. La debilidad de sus argumentos ponen de manifiesto la fragilidad e inutilidad de su posición para diseñar una política acerca de la pornografía que respete el marco de las libertades básicas. Una política que, teniendo como objetivo fundamental la salvaguarda de la autonomía de las personas y por lo tanto de sus propios planes de vida sexuales, sea capaz de evitar que se dañe a otro.

Según la tradición liberal, el Estado y el derecho deberían generar instituciones cuyo fin sea el desarrollo pleno de la personalidad del individuo. Instituciones que garanticen el orden público, prohíban ataques a la vida o bienes de las personas y posibiliten la realización incluso de aquellos proyectos de vida que no son compartidos mayoritariamente. La noción de daño ha de ser entendida en este contexto como un ataque a las condiciones que permiten alcanzar aquellos objetivos. Y respecto de la pornografía, para que su prohibición quede justificada habría que probar alguna de estas dos hipótesis: o bien que produce un daño, o bien que, sin ser en sí misma dañina, genera acciones que sí lo son. Pero como se ha puesto de manifiesto en los dos apartados anteriores, el feminismo radical no logra demostrar que la pornografía sea un «agente causal» de daño, en ninguna de las dos hipótesis señaladas.

La consideración de que los materiales pornográficos son mala in re, al ser un elemento que causa «degradación» o «subordinación» no se sostiene. La afirmación de K. MacKinnon y adláteres de que la pornografía daña carece de referente empírico, y constituye, en realidad, una frase puramente propagandística.

Que la pornografía genere acciones delictivas violentas tampoco ha podido ser demostrado. La continua apelación del feminismo radical a los trabajos de Edward Donnerstein invocando sus tesis de que una prolongada exposición a la pornografía violenta no sólo desensibiliza al hombre sino que produce una actitud más permisiva hacia los ataques sexuales a las mujeres se hace desde posiciones interesadas y dogmáticas. El mismo Donnerstein se encargó de señalar que sus propias investigaciones no son generalizables fuera del laboratorio. Además, en sus últimos trabajos concluyó que la excitación sexual no es necesaria para favorecer una actitud agresiva hacia las mujeres, es la violencia el primer elemento que ha de ser tomado en consideración. Los autores e instigadores del modelo de ordenanza de Indianápolis, al propugnar 
la prohibición de un material cuyo contenidos excedían las representaciones violentas, no podían apoyarse coherentemente para su justificación en las investigaciones invocadas ${ }^{56}$. Sumado a ello, el permanente acento que A. Dworkin y K. MacKinnon ponen sobre la pornografía violenta, a pesar de que ésta representa menos del uno por ciento del total, señala cómo los datos son utilizados con propósitos claramente distorsionadores. «Incluso si la ordenanza estuviera dirigida a la representación de la violencia, y fuera permitida, se abriría una Caja de Pandora de pretensiones acerca de que la violencia en televisión sea prohibida debido a los efectos causales similares ${ }^{57}$. Se propugnaría así una peligrosa vía de prohibiciones que conduciría al autoritarismo. La censura se sabe cuando comienza, pero no cuando termina.

Algunas feministas incluso ni tan siquiera consideran necesario presentar prueba fiables que muestren la relación causal entre pornografía y daño. Todo se reduciría a una mera cuestión de sentido común. Según asume Kathleen Barry, «las relaciones causales entre pornografía y violencia sexual son perfectamente evidentes. No necesitamos seguir a los hombres individualmente fuera de los teatros específicamente pornográficos y ser testigos de cómo violan a la primera mujer que ven para comprender como mujer cuál es el impacto que tiene la pornografía en nuestras vidas. Sólo necesitamos apelar a nuestro sentido común ${ }^{58}$. Y cuando se ofrecen evidencias en contrario o simplemente que no avalen ese especial «sentido común» es debido a que se participa del sadismo cultural. En palabras de la feminista estadounidense: «El hecho de que la Comisión sobre la Obscenidad y la Pornografía haya invertido muchos millones de dólares, muchos años y muchos volúmenes de investigación para tratar de refutar lo que es auto evidente y puede ser derivado del sentido común es un testimonio de su predisposición ideológica, su investigación sexista y sus valores masculinos» ${ }^{59}$. Para continuar en otro lado, «un análisis del estudio en que más se apoyó la Comisión como corroboración de estos resultados sugiere que los prejuicios liberales de los integrantes de la Comisión enturbiaron la objetividad con que deberían haber cumplido su cometido... Sus resultados fueron un producto de la historia y la ideología del

${ }^{56}$ Véase Thomas, A. McWatters III, «An Attempt to Regulate Pornography through Civil Rights Legislation: is it Constitutional?», Toledo Law Review, vol. 16, 1984, pág. 307.

${ }^{57}$ Idem.

${ }^{58}$ Véase K. Barry, «Beyond Pornography: From Defensive Politics to Creating a Vision», en

Ledere, L. (ed.) Take Back the Night, ob. cit. pág. 311.

${ }^{59}$ Idem. 
sadismo cultural, en vez 
de atenerse a la búsqueda real de la verdad» ${ }^{60}$. Dudo mucho que el particular «sentido común» de las feministas radicales constituya un método idóneo para determinar la verdad de un enunciado, y ni tan siquiera para buscarla. Por otra parte, no creo necesario advertir sobre los peligros que se ciernen si se acepta como criterio justificatorio de la censura estatal el «sentido común» de alguien, al margen o en contra de las pruebas fiables ofrecidas. Las ideas preconcebidas tan propias de una posición perfeccionista aflora nuevamente en el feminismo radical, esta vez por boca de K. Barry.

Pero el hecho que no se haya podido probar que la pornografía causa daño y de la asunción de las tesis liberales enunciadas con anterioridad no se debe inferir que la pornografía no debe ser regulada sin más. En efecto, una política respecto de la pornografía que no tome en consideración a los niños y a las llamadas «audiencias cautivas» carecería de justificación.

La vinculación de los niños a la pornografía hace surgir ciertos problemas que no aparecen con los adultos. El bienestar de los niños debe constituir una preocupación central de la política estatal. Permitir que se comprometan en acciones pornográficas a través de la producción o de su consumo podría dar lugar al padecimiento de algún daño dada su incapacidad para comprender la naturaleza de tales acciones. Debería prohibirse, pues, su participación en la producción de pornografía para impedir que sean víctimas de abusos o explotación. Y debería prohibírseles asimismo su consumo con el fin de que no se dañen a sí mismos. El primer argumento se basa en el principio del daño a otros, el segundo en consideraciones paternalistas. Que los niños sean una de las clases de lo que Ernesto Garzón Valdés denominó «incompetentes básicos» justifica una restricción de sus libertades con fines benevolentes ${ }^{61}$.

No pocos esfuerzos de las feministas radicales han sido dirigidos a tratar de mostrar que, en las sociedades actuales, la mujer se encuentra en una situación semejante a la de los niños. K. MacKinnon, por ejemplo, propone la aplicación a las mujeres de la doctrina que surge del caso Ferber en los Estados Unidos que admite la constitucionalidad de la persecución penal de la pornografía infantil. Según esta doctrina, es razonable pensar que se produce un daño mental, emocional y fisiológico en los niños

${ }^{60}$ Véase K. Barry, Esclavitud sexual de la mujer, ob. cit. pág. 256.

${ }^{61}$ Para una caracterización de la figura del «incompetente básico» y las condiciones requeridas para que una intervención paternalista sea justificada, véase: Ernesto Garzón Valdés, «¿Es éticamente justificable el paternalismo jurídico?». DOXA, n. ${ }^{\circ} 5,1988$, págs. 155 y ss. 
cuando intervienen en la producción de pornografía, y dado que la pornografía infantil tiene además un valor social mínimo debe ser eliminada del mercado con el fin de proteger a los menores. Y aunque la propia feminista estadounidense sostiene que las mujeres no son niños, en la nota de la misma página de su trabajo a la cual nos remite afirma: «dado lo que se ofrece en la pornografía resulta más difícil de lo común determinar la diferencia entre adultos y niños. Las mujeres adultas son infantilizadas en la pornografía; los niños son vestidos y usados como si fueran mujeres adultas.... $\rangle^{62}$. Al margen de la confusión que es capaz de introducir K. MacKinnon al decir en muy pocas líneas que a las mujeres hay que tratarlas como niños a pesar de que las mujeres no son niños, pero que al mismo tiempo cada vez es más difícil distinguir entre niños y adultos, se esconde la idea de que en la pornografía -y no sólo en ella- las mujeres siempre son coaccionadas, ya sea de un modo físico, cultural o económico. El papel de la mujer en la sociedad, con independencia de su ubicación social, cultural o económica, es de subordinación y explotación. Todos los miembros de la clase del sexo femenino, por el mero hecho de pertenecer a ella, siempre son de alguna forma discriminados negativamente y sojuzgados. Bajo este prisma, el supuesto consentimiento que prestan las mujeres a la ejecución de acciones pornográficas -y a otro tipo de acciones, claro está- al haber sido otorgado en una situación de coacción resulta viciado y, por consiguiente, carece de valor. Ya el modelo de ordenanza examinado se hacía eco de este punto. La negativa del feminismo radical a tratar a las mujeres que de una manera voluntaria no comparten sus estereotipos sexuales como seres carentes de autonomía es una constante. «La cuestión no es sólo que cuando la mujer puede ser coaccionada con impunidad -afirma K. MacKinnon- tiene como resultado un conjunto de pautas que son devastadoras y peligrosas para todas las mujeres. La cuestión es también que los presupuestos que la disposición de la Primera Enmienda asume respecto de los adultos -que son autónomos, que se definen a sí mismos, que actúan libremente, que son individuos iguales- son exactamente aquellas cualidades que la pornografía niega y socava sistemáticamente a la mujer» ${ }^{63}$. En estas circunstancias, la situación de indefensión en la que se encontrarían las mujeres no diferiría en demasía con la de los niños.

Además, las mujeres al formar parte de una sociedad donde

${ }^{62}$ Véase K. MacKinnon, «Pornography, Civil Rights and Speech», Harvard Civil Rights-Civil Liberties Law Review, vol. 20, 1985, pág. 38, nota 77.

${ }^{63}$ Idem, pág. 36. 
impera el sadismo cultural serían tratadas como objetos y como tales serían poseídas, golpeadas o muertas si no se muestran aquiescentes. Que esa aquiescencia pudiera ser considerada como consentimiento sería más que dudoso ${ }^{64}$. La generación de un proceso donde impera el sadismo cultural, por otra parte, crearía en la conciencia general falsas concepciones que sirven para justificar las desigualdades y el sometimiento. Al estar dotadas de una falsa conciencia, las mujeres no serían capaces de comprender sus verdaderos intereses, ni de tomar iniciativas que les permitan alcanzar sus propios fines. Las mujeres serían «incompetentes básicos». La conformidad que supuestamente prestarían a las prácticas sociales o sexuales no podrían constituir, por lo tanto, consentimiento alguno. Pero todas estas consideraciones requieren un análisis algo más detallado.

Es evidente que involucrar a niños en las actividades sexuales de los adultos es ilegal en cualquier contexto, y no sólo en la pornografía. Su falta de madurez es indiscutible. $\mathrm{Y}$ el derecho no debe proteger las representaciones y los beneficios que se obtienen a través de esos actos ilícitos. El caso de una mujer adulta es, sin embargo, completamente diferente. Es verdad que se comete un delito si una persona -sea hombre o mujer- es coaccionada para ejecutar acciones pornográficas o de otro tipo. Para imponer sanciones a los autores de esas prácticas no es necesario ninguna ordenanza antipornográfica, basta la aplicación de la legislación general vigente. Las medidas propuestas por A. Dworkin y K. MacKinnon son, en este sentido, superfluas. Prohíben lo que ya estaba prohibido.

Pero del hecho de que alguna mujer sea coaccionada no se sigue que todas lo sean. Es una cuestión empírica. Es concebible pensar que una mujer adulta puede elegir de una manera inteligente, libre e independiente ejecutar acciones pornográficas, si así lo hace no habría coacción o daño. Aquí la fórmula Volenti non fit injuria adquiere plena vigencia. Pensar que las mujeres carecen de una capacidad para consentir es transformarlas precisamente en seres discapacitados. Y ya la propia Corte Suprema de los EE.UU. en el caso American Booksellers vs. Hudnut estableció la imposibilidad de transferir la doctrina Ferber a las mujeres como clase. En palabras del Juez Baker, «las mujeres adultas tienen generalmente la capacidad de protegerse a sí mismas de participar en la pornografía y de ser victimizada por ella.... ${ }^{65}$.

${ }^{64}$ Véase K. Barry, Esclavitud sexual de la mujer, ob. cit. especialmente págs. 237 y 273.

${ }^{65}$ Para un análisis en detalle de esta cuestión, véase Ann I. Park, «Feminism, 
Por otra parte, si se extiende el argumento de asimilación de la mujer a los niños de K. MacKinnon se llega a la conclusión de que es degradante para la mujer, ya que implica que no tiene más capacidad deliberativa que un niño. En efecto, «el presupuesto fuerte de la ordenanza acerca de la coerción es también objetable porque refuerza la noción sexista de que las mujeres son incapaces de consentir... Las comparaciones entre las mujeres y los niños pueden servir únicamente para reforzar los estereotipos de las mujeres ${ }^{66}$.

Finalmente, considerar a la mujer como un ser carente de capacidad para consentir es muy peligroso, sobre todo para las propias mujeres. En efecto, el transformarlas en «incompetentes básicos» abre las puertas a las intervenciones paternalistas. Pero en toda intervención paternalista ha de existir una autoridad paternalista. Y la primera cuestión a dilucidar es, sin duda, quien será esa autoridad. Naturalmente, no puede ser el Estado, puesto que ha sido definido como un instrumento por el cual se somete a la mujer. Tampoco pueden ser la propias mujeres, ya que todas, por definición del feminismo radical, están munidas de una falsa conciencia y, por ende, discapacitadas. De lo que resulta que es el hombre el único que podría ejercer un benevolente manto protector. No conozco ninguna otra formulación más clara de una supuesta justificación de la dominación masculina que la ofrecida por esta versión del feminismo. A menos, claro está, que las propias feministas se autoadscriban la propiedad de estar «liberadas» de las cargas ideológicas que por las generales de la ley les correspondería. Pero mucho me temo que tal supuesto traería aparejados serios problemas conceptuales, al tiempo que sentaría las bases para la imposición de medidas arbitrarias y personalistas.

La expresión «audiencias cautivas» se ha utilizado para denotar aquellas personas que se sienten «atrapadas» por un fenómeno, en este caso el consumo de pornografía, sin desearlo. El reconocimiento de la autonomía de las personas exige que se respeten sus propios planes de vida, al mismo tiempo que obliga al Estado a tomar las medidas suficientes para impedir la imposición de lo indeseado. Ya el Informe Williams alertaba sobre los peligros de una falta absoluta de regulación de la pornografía por el daño que se inflingiría a tales audiencias. Con el objeto de evitarlo, se ha propuesto tradicionalmente que la exposición y venta de materiales

Pornography, and the First Amendment: An Obscenity-Based Analysis of Proposed Antipornography Laws», UCLA Law Review, vol. 34, 1987, págs. 1265 y ss. La cita en pág. 1282.

${ }^{66}$ Véase Rebecca Benson, «Pornography and the First Amendment: American Booksellers vs. Hudnut», Harvard Women's Law Journal, vol. 9, 1986, pág. 172. 
pornográficos se realice en locales adecuados, destinados exclusivamente a esos fines y debidamente identificados. El rechazo de las feministas radicales a estas medidas es manifiesto. En efecto, la posición de las feministas es que la pornografía es tan omnipresente en la sociedad y el impacto que provoca es tan dañino que se hace imposible evitarla. Todos seríamos cautivos de ese fenómeno. Nuevamente aparecen aquí las significativas coincidencias entre las feministas radicales y las fuerzas más conservadoras de la sociedad. Pero que una persona sea «atrapada» y obligada a consumir algo en contra de su voluntad constituye nuevamente una cuestión empírica, no conceptual. Las tesis feministas en este punto son absolutamente exageradas y sin fundamento alguno. De la afirmación razonable de que hay que tomar medidas legislativas que regulen la producción y consumo de la pornografía para impedir el daño a los miembros de las audiencias cautivas se pasa, en virtud de las exageraciones feministas, a la implausible tesis de que dado que todos los seres humanos somos miembros de las audiencias cautivas debe prohibirse absolutamente la pornografía.

Con la finalidad de evitar el daño a los niños y a las audiencias cautivas, el Estado debería imponer restricciones de carácter espacial y temporal, en la dirección ya adelantada. Con ello se evita la prohibición de la producción y consumo de pornografía para aquellos que la incluyen en su proyecto de vida sexual, y que puede llegar a constituir una parte importante de su propio plan de vida. También así se sortea el problema de los niños y de quien no desea verse enfrentado a la pornografía y consumirla contra su voluntad. En ambos casos se garantiza el desarrollo de la autonomía personal. Todo lo que exceda de esas medidas carece de legitimidad. Haber mostrado que las feministas radicales mantienen tesis que conducen inexorablemente al perfeccionismo moral o al paternalismo no justificado señala el carácter éticamente inaceptable de sus posiciones. El modelo de ordenanza antipornográfico constituye un buen ejemplo de ello.

Que la ordenanza aquí analizada no haya superado la prueba de constitucionalidad impidió la imposición de una dudosa moralidad. «Uno de los aspectos más conflictivos del procedimiento de censura de Indianápolis es que permite a un cuerpo político sensible actuar por medio de una ley muy vaga, confusa y lógicamente inconsistente y en base a una afirmación filosófica casta para determinar cuál es la verdadera imagen que de un grupo se ha de representar en todas las formas de comunicación y en cualquier circunstancia. Precisamente es este tipo de actividad censoria que la Suprema Corte de los EE.UU. ha tratado de impedir mediante 
una serie de decisiones que han establecido límites específicos a la censura...» ${ }^{67}$.

Pero si la ordenanza de Indianápolis fue declarada inconstitucional y las tesis del feminismo radical se manifiestan moralmente inaceptable, no cabe duda, además, que la táctica política empleada por las feministas antipornografía resultó inadecuada. De hecho, al propiciar un clima político conservador, la ordenanza sirvió para la persecución de minorías sexuales como los homosexuales o las feministas lesbianas. «En Suffolk Country, Nueva York, la ordenanza antipornografía fue enmendada para atacar a los homosexuales al incluir la sodomía como un mal fomentado por la pornografía» ${ }^{68}$.

Por otra parte, la ordenanza permite requisar de librerías y comercios casi cualquier material explícitamente sexual dada la vaguedad y ambigüedad de sus términos. Ello dio lugar a que fuera utilizada contra la literatura y demás formas de expresión artística que representaban aspectos de la vida, creencias o vivencias de la comunidad feminista, lesbiana u homosexual. En Canadá, sobre una base legal similar e inspirado en el lenguaje y con los presupuestos propios del feminismo radical se censuró películas feministas, entre las cuales se encontraba una crítica feminista a la pornografía titulada «Not a Love Story» ${ }^{69}$. En otros casos se prohibieron libros y materiales en favor del aborto o de las prácticas anticonceptivas.

Tampoco queda claro que una ordenanza represiva sea una táctica política capaz de modificar las creencias de las mujeres. Mientras al mismo tiempo se plantean serias dificultades para comprender cómo pueden confiar las feministas que el sistema jurídico otorgue remedios para las víctimas de la pornografía si previamente definieron al derecho como masculino y opresor de la mujer.

Además, la historia de la ordenanza permite obtener lecciones políticas importantes. Cuando fue propuesta por primera vez en Minneápolis logró un fuerte apoyo del colectivo feminista en general. Pero pasado el tiempo y a medida que otros proyectos similares alcanzaban las ciudades de Indianápolis, Suffolk Country y Wisconsin, entre otras, ese soporte se fue debilitando, a la vez que se desplazaba y se concentraba aún más en las feministas

67 Véase William Brigman, «Pornography as Group Libel: The Indianapolis Sex Discrimination Ordinande», ob. cit. pág. 505. El subrayado es mío.

${ }^{68}$ Véase Mary Lauby, Leslie Reagan y Daniel Grossberg «Feminists Propose Alternatives to Pornography Free Zone Campaign», Againts the Current, enero-febrero de 1986, pág. 39.

${ }^{69}$ Idem, pág. 40. 
radicales, las fuerzas más conservadoras y los grupos políticos antisexo ${ }^{70}$. Y fue utilizada, en definitiva, como un arma arrojadiza contra buena parte de las feministas (no radicales) y contra buena parte de sus reivindicaciones históricas.

Finalmente, «la ordenanza supone que las mujeres como una clase (y sólo las mujeres) son subordinadas por cualquier imagen explícitamente sexual... Y supone que los hombres como una clase (y sólo los hombres) son condicionados por representaciones explícitamente sexuales para cometer actos de agresión y crear mitos misógenos. Tales presupuestos refuerzan y perpetúan los principales estereotipos sexistas, debilitan en vez de incrementar la lucha de las mujeres para liberarse a sí mismas de las arcaicas nociones de los papeles sexuales... La ordenanza refuerza la visión estereotipada de que la mujer [buena] no ambiciona ni disfruta el sexo... y que las mujeres son tan frágiles y los hombres tan confiar en el rechazo o el disfrute de manifestaciones explícitamente sexuales decididos por ellos mismos»» ${ }^{71}$.

Buena parte de la crítica aquí presentada a la concepción del feminismo radical fue de tipo conceptual. En otro lugar definí a la pornografía como la representación de manifestaciones explícitamente sexuales que habitualmente pertenecen a la esfera privada del ser humano realizadas con la intención de producir la excitación sexual de sus destinatarios y de alcanzar ese objetivo ${ }^{72}$. En mi opinión, esta noción, cuyos elementos no analizaré nuevamente ahora, capta el núcleo significativo del término pornografía. Las diferencias con el concepto propuesto por A. Dworkin y C. MacKinnon son notables. Pero mis diferencias no se reducen sólo a los aspectos definicionales. Creo haber mostrado las carencias teóricas, los errores argumentativos, las inexactitudes de carácter empírico, la inadecuación de las tácticas políticas utilizadas y la inaceptabilidad ética de las posiciones del feminismo radical, al menos en lo que concierne a la pornografía. Y si se parte de la tesis del liberalismo moral y del respeto a la autonomía de las personas se tendrá que concluir con las siguientes palabras de Ronald Dworkin, «el derecho a la independencia moral, si es un derecho genuino, requiere una actitud jurídica permisiva hacia el consumo de pornografía

${ }^{70}$ Véase Rebecca Benson, «Pornography and the First Amendment...» ob. cit. pág. 172.

${ }^{71}$ Véase Paul Brest y Ann Vandenberg, «Politics, Feminism and the Constitution...», ob. cit. pág. 655 .

${ }^{72}$ Véase Jorge F. Malem Seña, «Acerca de la pornografía», ob. cit. pág. 224. 
en privado» ${ }^{73}$.

${ }^{73}$ Véase Ronald Dworkin, A Matter of Principle. Cambridge University Press. Massachusetts, 1985 , pág. 358. 